\title{
Residential Speed Limit Reduction Case Studies
}

\author{
Ginger M. Rossy ${ }^{1}$, Carlos C. Sun ${ }^{*}$, , Dan Jessen $^{2}$ and Earl Newman ${ }^{3}$ \\ ${ }^{I}$ Department of Civil and Environmental Engineering, University of Missouri, E2509 Laferre Hall, Columbia, MO \\ 65211, USA \\ ${ }^{2}$ City of Springfield Department of Public Works, Springfield, MO, USA \\ ${ }^{3}$ College of Natural and Applied Sciences, Missouri State University, Springfield, MO, USA
}

\begin{abstract}
Speeding on residential/neighborhood streets is a common citizen complaint, but previous research on the effects of lowering speed limits has been limited mostly to high-volume, high-speed roads. On such facilities, studies indicated that a reduction in speed was not commonly attained by reducing the posted speed limits alone. This paper describes residential studies in the United States in Springfield and Columbia that found speed limit reductions from 30 $\mathrm{mph}(48 \mathrm{~km} / \mathrm{h})$ to $25 \mathrm{mph}(40 \mathrm{~km} / \mathrm{h})$ did produce statistically significant speed decreases. In addition to the speed limit reduction, other issues investigated were the use of specialized speed limit signs containing a yellow border and an additional safety message, pace car stickers and neighborhood educational campaigns. The engineering studies were used by each City to guide their decisions to lower residential speed limits citywide.
\end{abstract}

Keywords: Speed limit, residential street, speed study, pace car, speeding.

\section{INTRODUCTION}

In 2008, the Fatality Analysis Reporting System Encyclopedia [1] reported 34,017 fatal crashes in the United States. Only10 percent $(10 \%)$ of these occurred in areas where the posted speed limit was 30 miles per hour (mph) (48 kilometers per hour) or lower. The large percentage of fatal crashes that occur at speeds higher than $30 \mathrm{mph}(48$ $\mathrm{km} / \mathrm{h}$ ) is one explanation for the large amount of research performed on higher speed roads and the correspondingly small amount of research on lower speed roads. However, local road miles account for $68.6 \%$ of the total road mileage in the United States and $13.4 \%$ of the total travel [2]. Local roads include residential streets, and city councils across the United States commonly receive complaints about speeding in neighborhoods [3]. Whether real or perceived, speeds above the posted speed limits in residential areas create numerous other problems. As an example, the Federal Highway Administration created the Safe Routes to School (SRTS) Program [4] to investigate the reasons why less than $20 \%$ of the children in the United States walk to school and only $6 \%$ ride bicycles. Traffic danger was cited as the second worst barrier to children walking and bicycling to school (40 $\%$ of the surveyed population), preceded only by the distance to school [5].

The Transport Research Laboratory estimated that each onemph speed reduction in average traffic provided a reduction of $6 \%$ in vehicle accidents for urban main roads and residential roads with low average speeds [6]. For the 2008 FARS (Fatal Analysis Reporting System) data

*Address correspondence to this author at the Department of Civil and Environmental Engineering, University of Missouri, E2509 Laferre Hall, Columbia, MO 65211, USA; Tel: (573) 884-8330; Fax: (573) 882-4784;

E-mail: csun@missouri.edu presented previously, this could represent a decrease of 204 fatal crashes per year. The question is: Can average speeds be lowered in residential areas by simply lowering the posted speed limits?

Previous research showed that in rural and urban highways with posted speed limits between 20 and $55 \mathrm{mph}$ (32 to 88.5 $\mathrm{km} / \mathrm{h})$, there was less than a $1.5 \mathrm{mph}(2.4 \mathrm{~km} / \mathrm{h})$ average change in speeds when speed limits were reduced. These average changes were not statistically significant to the 95 th percentile confidence level [7]. Surveys from the speed limit reduction efforts of various cities suggested that lowering the posted speed limits was not enough to modify drivers' behaviors [3]. Other measures like road modification, police enforcement and educational campaigns must also be implemented.

This article presents the results from two independent studies in Missouri: one performed by the City of Springfield Public Works and the other by the University of Missouri in Columbia. In both cities, the posted speed limit was $30 \mathrm{mph}$ (48 $\mathrm{km} / \mathrm{h}$ ) and local residents requested a reduction to $25 \mathrm{mph}$ speed limit $(40 \mathrm{~km} / \mathrm{h})$. In both cities, pilot projects were performed in selected neighborhoods to determine if, by lowering posted speed limits, average and 85 th percentile speeds could be effectively lowered. This was evaluated by comparing average speeds before and after the posted speed limit reduction. Even though "residential street" does not have a precise engineering definition, in this study it refers to streets located within the boundaries of a residential neighborhood and with low volumes $(<1000$ ADT $)$, low speeds, and high residential density.

\section{MATERIALS AND METHODOLOGY}

\section{The Springfield, Mo Pilot Project}

In 2005 over 180 residents from the Rountree [sic] neighborhood in Springfield, Missouri, signed a petition 
requesting the reduction in posted speed limit in their neighborhood from $30 \mathrm{mph}(48 \mathrm{~km} / \mathrm{h})$ to $25 \mathrm{mph}(40 \mathrm{~km} / \mathrm{h})$ [8]. The City of Springfield Traffic Engineering office included the following two major components into the speed limit reduction pilot project. First, some of the new $25 \mathrm{mph}$ $(40 \mathrm{~km} / \mathrm{h})$ speed limit would be displayed in oversized signs, each including a positive safety message such as "Kid Friendly", "Set the Pace" or "Respect the Limit". Also each sign would have an attention-attracting yellow border (e.g. Fig. 1) around a standard Manual of Uniform Traffic Control Devices (MUTCD) [9] speed limit sign. These special signs would be placed only at the entrances to the neighborhood. In two locations within the neighborhood, the conventional speed limit signs were moved from the side of the road to temporary islands in the middle of the road to make the signs more visible.

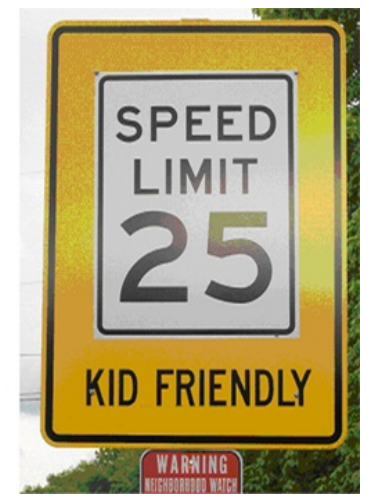

Fig. (1). Example of oversized speed limit signs used on both pilot projects.

The second component of the pilot project consisted of the Pace Car Program. The Pace Car Program was modeled after a similar program developed in Salt Lake City, Utah [10]. Under this program, residents of the Rountree neighborhood would sign a pledge to drive within the speed limit and become a Pace Car driver to set an example for other motorists to follow. The purposes of the program included persuading drivers to reduce speed, promote courteous driving habits, and raise the awareness that residential streets must be shared between vehicles, bicycles and pedestrians. Only streets functionally classified as "local" would receive the $5 \mathrm{mph}(8 \mathrm{~km} / \mathrm{h})$ posted speed limit reduction. As defined by the Federal Highway Administration, local roads are roads that are not arterials or collectors and are characterized as having low mobility and high degree of access [11]. The Springfield City Council approved the pilot project in September, 2005 and research was performed from October, 2005 to October, 2006.

The Springfield pilot project involved speed and volume data at two separate locations on each of five roads that crossed the Rountree neighborhood from north to south. The first data collection occurred on October 2005, before the speed limits were reduced to $25 \mathrm{mph}(40 \mathrm{~km} / \mathrm{h})$. The $25 \mathrm{mph}$ $(40 \mathrm{~km} / \mathrm{h})$ speed limit reduction occurred on November 3, 2005. Speed and volume readings were collected once per month at the same locations. Each reading consisted of 48 hours of continuous speed and volume readings. All of the data was collected on Tuesdays and Wednesdays as is typical of traffic studies.
Three of the roads where data was collected, Kickapoo, Weller and Pickwick, were classified as local. The other two roads, Freemont and Delaware avenues, were classified as collectors; therefore, speeds were not lowered to $25 \mathrm{mph}$ (40 $\mathrm{km} / \mathrm{h}$ ). No special enforcement other than the Pace Car program was implemented in the area during the study.

\section{RESULTS AND DISCUSSION}

Table 1 presents a summary of the Springfield data collection dates, average speeds and average daily volumes. Average speeds and standard deviations for the beginning and end of the one year period were compared. Statistical tests determined if average speeds had been lowered as a result of posting the reduced speed limit and the implementation of the Pace Car program. Table 2 shows a summary of the statistical data analysis. The Average Speed Difference column reflects the total difference in average speeds between the data collected on October, 2005 and October 2006. A positive value in this column represents a decrease in average speed. The independent heteroscedastic $t$ test was used to assess the statistical significance of the difference in average speeds. The $t$ test is based on the premise that under certain conditions the $t$ statistic computed from two samples acquired from two independent processes follows a Student's t distribution [12]. If the t test results are significant, then the two samples are considered to be drawn from different populations; thus indicating that the speed differences are not due to randomness. The $p$ value shown in Table $\mathbf{2}$ is calculated using the Student $\mathrm{t}$ distribution and, typically, a p-value of less than 0.05 (i.e. $5 \%$ significance level, or $95 \%$ confidence level) is considered to be statistically significant. Also shown in Table 2, is the difference in 85 th percentile speeds and the percent $(\%)$ change in observed average speeds.

Table 2 shows that all of the roads where the speed limit reduction occurred (Kickapoo, Pickwick and Weller streets) experienced a reduction in average speed. The average speed reduction ranged between $0.41 \mathrm{mph}(0.66 \mathrm{~km} / \mathrm{h})$ and 4.02 $\mathrm{mph}(6.47 \mathrm{~km} / \mathrm{h})$ or $1.6 \%$ and $13.5 \%$, and all $\mathrm{p}$ values showed the reductions were statistically significant. Evaluation of the experimental data yielded minimal changes in variance, which suggested uniform driver population compliance to the new speed limit. The relatively unchanged speed variance is important, since safety gains from average speed reductions can be counter-balanced by an increase in speed variance. The benefits of reducing speed limits on residential streets were carried over to the collector streets around the Rountree neighborhood. Table 2 shows five of the eight data sites on Delaware and Freemont avenues, where the posted speed limit remained at $30 \mathrm{mph}(48 \mathrm{~km} / \mathrm{h})$, also experienced reductions in average speeds ranging between 0.29 and $1.18 \mathrm{mph}(0.47$ and $1.90 \mathrm{~km} / \mathrm{h})$. There were three locations where the speeds increased but those increases were not statistically significant.

\section{MATERIALS AND METHODOLOGY}

\section{The Columbia, Mo Pilot Project}

In 2008, the City Council of Columbia, MO cited high speeds in residential areas as the number one complaint from Columbia residents [3]. As a result, a study was conducted to 
Table 1. Data Collection Summary for Rountree in Springfield, Missouri

\begin{tabular}{|c|c|c|c|c|c|c|}
\hline \multirow{2}{*}{ Street } & \multirow{2}{*}{ Direction } & \multicolumn{2}{|c|}{ Collection Dates } & \multicolumn{2}{|c|}{ Average Speed } & \multirow{2}{*}{$\begin{array}{c}\text { Average Daily } \\
\text { Traffic }\end{array}$} \\
\hline & & Start & End & (mph) & $(\mathrm{km} / \mathrm{h})$ & \\
\hline DELAWARE & S OF MADISON NB & $10 / 11 / 05$ & $10 / 12 / 05$ & 27.80 & 44.73 & 404.00 \\
\hline DELAWARE & S OF MADISON NB & $10 / 3 / 06$ & $10 / 4 / 06$ & 26.82 & 43.17 & 474.00 \\
\hline DELAWARE & S OF MADISON SB & $10 / 11 / 05$ & $10 / 12 / 05$ & 27.38 & 44.06 & 323.50 \\
\hline DELAWARE & S OF MADISON SB & $10 / 3 / 06$ & $10 / 4 / 06$ & 27.87 & 44.86 & 428.50 \\
\hline DELAWARE & S OF MONROE NB & $10 / 11 / 05$ & $10 / 12 / 05$ & 28.83 & 46.40 & 347.00 \\
\hline DELAWARE & S OF MONROE NB & $10 / 3 / 06$ & $10 / 4 / 06$ & 28.52 & 45.89 & 415.00 \\
\hline DELAWARE & S OF MONROE SB & $10 / 11 / 05$ & $10 / 12 / 05$ & 27.57 & 44.36 & 239.50 \\
\hline DELAWARE & S OF MONROE SB & $10 / 3 / 06$ & $10 / 4 / 06$ & 26.38 & 42.46 & 297.50 \\
\hline FREEMAN & S OF MADISON NB & $10 / 11 / 05$ & $10 / 12 / 05$ & 30.54 & 49.14 & 1198.50 \\
\hline FREEMAN & S OF MADISON NB & $10 / 3 / 06$ & $10 / 4 / 06$ & 29.78 & 47.92 & 1691.50 \\
\hline FREEMAN & S OF MADISON SB & $10 / 11 / 05$ & $10 / 12 / 05$ & 31.74 & 51.08 & 936.50 \\
\hline FREEMAN & S OF MADISON SB & $10 / 3 / 06$ & $10 / 4 / 06$ & 31.45 & 50.61 & 945.50 \\
\hline FREEMAN & S OF MONROE NB & $10 / 11 / 05$ & $10 / 12 / 05$ & 29.12 & 46.86 & 1519.00 \\
\hline FREEMAN & S OF MONROE NB & $10 / 3 / 06$ & $10 / 4 / 06$ & 30.02 & 48.31 & 1672.00 \\
\hline FREEMAN & S OF MONROE SB & $10 / 11 / 05$ & $10 / 12 / 05$ & 29.65 & 47.71 & 891.00 \\
\hline FREEMAN & S OF MONROE SB & $10 / 3 / 06$ & $10 / 4 / 06$ & 30.09 & 48.42 & 917.00 \\
\hline KICKAPOO & S OF MADISON NB & $10 / 11 / 05$ & $10 / 12 / 05$ & 28.42 & 45.73 & 721.00 \\
\hline KICKAPOO & S OF MADISON NB & $10 / 3 / 06$ & $10 / 4 / 06$ & 27.17 & 43.72 & 676.50 \\
\hline KICKAPOO & S OF MADISON SB & $10 / 11 / 05$ & $10 / 12 / 05$ & 29.14 & 46.90 & 1005.50 \\
\hline KICKAPOO & S OF MADISON SB & $10 / 3 / 06$ & $10 / 4 / 06$ & 27.57 & 44.37 & 1039.00 \\
\hline KICKAPOO & S OF MONROE NB & $10 / 11 / 05$ & $10 / 12 / 05$ & 29.46 & 47.41 & 528.00 \\
\hline KICKAPOO & S OF MONROE NB & $10 / 3 / 06$ & $10 / 4 / 06$ & 27.42 & 44.13 & 486.00 \\
\hline KICKAPOO & S OF MONROE SB & $10 / 11 / 05$ & $10 / 12 / 05$ & 30.12 & 48.47 & 579.50 \\
\hline KICKAPOO & S OF MONROE SB & $10 / 3 / 06$ & $10 / 4 / 06$ & 28.38 & 45.67 & 543.00 \\
\hline PICKWICK & S OF MADISON NB & $10 / 11 / 05$ & $10 / 12 / 05$ & 28.64 & 46.09 & 476.50 \\
\hline PICKWICK & S OF MADISON NB & $10 / 3 / 06$ & $10 / 4 / 06$ & 26.21 & 42.18 & 397.00 \\
\hline PICKWICK & S OF MADISON SB & $10 / 11 / 05$ & $10 / 12 / 05$ & 29.02 & 46.70 & 559.50 \\
\hline PICKWICK & S OF MADISON SB & $10 / 3 / 06$ & $10 / 4 / 06$ & 26.80 & 43.13 & 487.50 \\
\hline PICKWICK & S OF MONROE NB & $10 / 11 / 05$ & $10 / 12 / 05$ & 28.69 & 46.17 & 461.00 \\
\hline PICKWICK & S OF MONROE NB & $10 / 3 / 06$ & $10 / 4 / 06$ & 24.84 & 39.98 & 395.00 \\
\hline PICKWICK & S OF MONROE SB & $10 / 11 / 05$ & $10 / 12 / 05$ & 29.84 & 48.03 & 542.50 \\
\hline PICKWICK & S OF MONROE SB & $10 / 3 / 06$ & $10 / 4 / 06$ & 25.82 & 41.56 & 500.50 \\
\hline WELLER & S OF MADISON NB & $10 / 11 / 05$ & $10 / 12 / 05$ & 25.55 & 41.12 & 350.50 \\
\hline WELLER & S OF MADISON NB & $10 / 3 / 06$ & $10 / 4 / 06$ & 24.76 & 39.85 & 313.50 \\
\hline WELLER & S OF MADISON SB & $10 / 11 / 05$ & $10 / 12 / 05$ & 26.88 & 43.26 & 395.50 \\
\hline WELLER & S OF MADISON SB & $10 / 3 / 06$ & $10 / 4 / 06$ & 26.45 & 42.56 & 393.50 \\
\hline WELLER & S OF MONROE NB & $10 / 11 / 05$ & $10 / 12 / 05$ & 25.58 & 41.17 & 344.00 \\
\hline WELLER & S OF MONROE NB & $10 / 3 / 06$ & $10 / 4 / 06$ & 24.19 & 38.93 & 321.00 \\
\hline WELLER & S OF MONROE SB & $10 / 11 / 05$ & $10 / 12 / 05$ & 25.88 & 41.64 & 385.00 \\
\hline WELLER & S OF MONROE SB & $10 / 3 / 06$ & $10 / 4 / 06$ & 25.46 & 40.98 & 398.50 \\
\hline
\end{tabular}


Table 2. Summary of Statistical Tests Performed on Springfield Data

\begin{tabular}{|c|c|c|c|c|c|c|c|c|}
\hline Neighborhood & Street & $\begin{array}{l}\text { Direction and } \\
\text { Location }\end{array}$ & $\begin{array}{l}\Delta \text { Ave. Spd. } \\
(\mathbf{k m} / \mathbf{h} / \mathbf{m p h})\end{array}$ & $\begin{array}{c}\text { Std. Dev. } \\
\text { Diff. }\end{array}$ & p Value & Stat. Sig.? & $\Delta 85 \%$ Spd. $(\mathrm{km} / \mathrm{h} / \mathrm{mph})$ & $\% \Delta$ Ave. Spd. \\
\hline Rountree & Delaware & SB, S of Madison & $1.56 / 0.97$ & 0.12 & $3.62 \mathrm{E}-35$ & Yes & $1.61 / 1.00$ & 3.49 \\
\hline Rountree & Delaware & $\mathrm{SB}, \mathrm{S}$ of Madison & $-0.80 /-0.50$ & 0.28 & large & No & $-1.61 /-1.00$ & -1.82 \\
\hline Rountree & Delaware & $\mathrm{SB}, \mathrm{S}$ of Madison & $0.51 / 0.32$ & 0.23 & $1.37 \mathrm{E}-03$ & Yes & $-0.805 /-0.50$ & 1.10 \\
\hline Rountree & Delaware & $\mathrm{SB}, \mathrm{S}$ of Monroe & $1.90 / 1.18$ & -0.33 & $1.68 \mathrm{E}-18$ & Yes & $1.08 / 0.67$ & 4.29 \\
\hline Rountree & Freemont & $\mathrm{NB}, \mathrm{S}$ of Madison & $1.22 / 0.76$ & 1.94 & $2.47 \mathrm{E}-35$ & Yes & $2.29 / 1.42$ & 2.49 \\
\hline Rountree & Freemont & $\mathrm{SB}, \mathrm{S}$ of Madison & $0.47 / 0.29$ & 0.32 & $1.618 \mathrm{E}-10$ & Yes & $0.451 / 0.28$ & 0.93 \\
\hline Rountree & Freemont & $\mathrm{NB}, \mathrm{S}$ of Monroe & $-1.45 /-0.90$ & 0.32 & large & No & $-1.29 /-0.80$ & -3.08 \\
\hline Rountree & Freemont & $\mathrm{SB}, \mathrm{S}$ of Monroe & $-0.71 /-0.44$ & 0.13 & large & No & $-0.451 /-0.28$ & -1.49 \\
\hline Rountree & Kickapoo & $\mathrm{NB}, \mathrm{S}$ of Madison & $2.01 / 1.25$ & -0.14 & $2.05 \mathrm{E}-144$ & Yes & $2.33 / 1.45$ & 4.40 \\
\hline Rountree & Kickapoo & $\mathrm{SB}, \mathrm{S}$ of Madison & $2.53 / 1.57$ & -0.11 & 0 & Yes & $2.69 / 1.67$ & 5.38 \\
\hline Rountree & Kickapoo & NB, S of Monroe & $3.28 / 2.04$ & -0.25 & $6.02 \mathrm{E}-186$ & Yes & $3.56 / 2.21$ & 6.92 \\
\hline Rountree & Kickapoo & $\mathrm{SB}, \mathrm{S}$ of Monroe & $2.80 / 1.74$ & -0.38 & $4.20 \mathrm{E}-175$ & Yes & $1.95 / 1.21$ & 5.78 \\
\hline Rountree & Pickwick & $\mathrm{NB}, \mathrm{S}$ of Madison & $3.91 / 2.43$ & 0.29 & $1.30 \mathrm{E}-150$ & Yes & $3.70 / 2.30$ & 8.49 \\
\hline Rountree & Pickwick & $\mathrm{SB}, \mathrm{S}$ of Madison & $3.56 / 2.21$ & 0.05 & $5.87 \mathrm{E}-218$ & Yes & $3.17 / 1.97$ & 7.63 \\
\hline Rountree & Pickwick & $\mathrm{NB}, \mathrm{S}$ of Monroe & $6.20 / 3.85$ & 0.20 & 0 & Yes & $5.86 / 3.64$ & 13.41 \\
\hline Rountree & Pickwick & $\mathrm{SB}, \mathrm{S}$ of Monroe & $6.47 / 4.02$ & 0.19 & 0 & Yes & $6.74 / 4.19$ & 13.48 \\
\hline Rountree & Weller & $\mathrm{NB}, \mathrm{S}$ of Madison & $1.26 / 0.78$ & -0.14 & $1.07 \mathrm{E}-19$ & Yes & $0.708 / 0.44$ & 3.07 \\
\hline Rountree & Weller & $\mathrm{SB}, \mathrm{S}$ of Madison & $0.69 / 0.43$ & 0.01 & $2.96 \mathrm{E}-07$ & Yes & $0.386 / 0.24$ & 1.62 \\
\hline Rountree & Weller & NB, S of Monroe & $2.24 / 1.39$ & -0.59 & $6.74 \mathrm{E}-35$ & Yes & $0.885 / 0.55$ & 5.43 \\
\hline Rountree & Weller & $\mathrm{SB}, \mathrm{S}$ of Monroe & $0.66 / 0.41$ & -0.10 & $4.23 \mathrm{E}-06$ & Yes & $-0.805 /-0.50$ & 1.60 \\
\hline
\end{tabular}

investigate the effects of a posted speed limit reduction from $30 \mathrm{mph}$ to $25 \mathrm{mph}$. This study incorporated the experiences from the Springfield study. A pilot speed reduction project was conducted in two neighborhoods: Rothwell Heights and Shepard Boulevard. For both neighborhoods, the speed limits signs were located at the entrances to the neighborhood, and the speed detectors were generally located on streets inside the neighborhood. Only one detector, Audubon Street detector in the Shepard Boulevard neighborhood, was located close to a speed limit sign. The detector locations were chosen so as to avoid vertical curves and queues from intersections or school parking lots.

The Shepard study had three stages: (1) baseline or no treatments, (2) reduced speed limit signs and (3) additional educational campaign. The Rothwell study had only the first two stages. The first stage consisted in collecting speed and volume data from two streets in each neighborhood before changing the posted speed limits. Each data set consisted of 48 hours of continuous data collected on Tuesdays, Wednesdays and/or Thursdays. The data was collected using magnetic traffic detectors. The first data set was collected in Rothwell Heights on October, 2008 and the second in Shepard Boulevard also on October, 2008.

For the second stage, the new speed limit signs installed in Rothwell Heights were standard MUTCD. The new speed limit signs installed in the Shepard Boulevard neighborhood were oversized and had a yellow border similar to the ones used in the Springfield, MO pilot project (Fig. 1). Similar to stage one, 48 hours of continuous data were collected on the same two streets on February, 2009 in Rothwell Heights and on March 2009 in Shepard Boulevard.

The last stage consisted in determining if an educational campaign would provide further reduction in average speeds, even if a speed reduction had already occurred during stage two of the methodology. A local pedestrian and bicycling advocacy group, PedNet, administered the educational campaign in the Shepard Boulevard neighborhood. The Executive Director of PedNet gave a presentation on the importance of reducing speed limits in residential areas at the neighborhood association and parent teacher association meetings. During the two meetings, the residents were encouraged to sign a pledge similar to the Pace Car pledge from the Springfield, MO pilot project. Volunteers from PedNet also went door to door in the neighborhood to try and reach the residents that had not attended the two meetings. No educational campaign was administered for the Rothwell Heights neighborhood.

A resident survey of the reduced speed limit was administered since city councils were interested in residents' perceptions in addition to the engineering effectiveness. The survey was distributed after data collection was completed. A high sampling rate of around twenty-five percent and forty percent of the households for each neighborhood was achieved by canvassing the neighborhoods door-to-door and 
by distributing the surveys during homeowner association meetings and school open houses. The sample size was forty from Rothwell Heights and forty-two from Shepard Boulevard.

\section{RESULTS AND DISCUSSION}

Table 3 presents a summary of the Columbia data collection dates, average speed and average daily volumes. Table 4 shows a summary of the statistical tests performed in the two neighborhoods in Columbia. The parameters used and statistical tests are the same as those performed for the data collected in the Springfield pilot project. The $t$ test was also used to assess the statistical significance of the difference in average speeds. Table 4 shows all of the streets experienced statistically significant reductions in average speed. One potential challenge with the data from Audubon Street was that the data was collected near an elementary school where queuing occurred. Thus the congestion near the school might have naturally constrained speeds.

The last two rows in Table $\mathbf{4}$ show the summary of the results from the data obtained after performing the educational campaign in the Shepard neighborhood. The data from the educational campaign is compared against the data from the speed limit reduction alone. Table $\mathbf{4}$ shows there was a minimal reduction in average speeds on Audubon
Street $(0.67 \mathrm{mph} / 1.08 \mathrm{~km} / \mathrm{h}$ average speed reduction) that proved to be statistically significant. Although there was a higher reduction in average speed on Falcon Street, it was not statistically significant.

Further evaluation of the statistical analysis performed on data collected in the Columbia neighborhoods showed higher variations in standard deviations than those obtained using the Springfield data. For the Springfield data, the standard deviation for each of the original data sets was within the range of 0.81 to $2.35 \mathrm{mph}(1.30$ to $3.78 \mathrm{~km} / \mathrm{h})$. For the Columbia data sets the standard deviations ranged within 5.03 and $10.26 \mathrm{mph}(8.10$ to $16.51 \mathrm{~km} / \mathrm{h})$.

A summary of the answers to the surveys on residents' perception of safety, related to the speed limit reduction, is presented in Table 5. Not all the questions asked on the survey are presented in the summary. There was a significant difference between the two neighborhoods in terms of the awareness of speed limit reduction despite the fact that all speed limit signs entering a neighborhood were changed. This difference can be attributed to the educational campaign conducted at Shepard and not at Rothwell, to the oversized signs employed at Shepard, and perhaps to the difference in the duration of residency of those surveyed. It is interesting to note that a significant percentage of residents still believe that most vehicles are speeding through the neighborhoods.

Table 3. Summary of Data Collection Dates and Volumes in Columbia, Missouri

\begin{tabular}{|c|c|c|c|c|c|c|c|}
\hline \multirow{2}{*}{ Neighborhood } & \multirow{2}{*}{ Street } & \multirow{2}{*}{ Direction } & \multicolumn{2}{|c|}{ Data Collection Dates } & \multicolumn{2}{|c|}{ Average Speed } & \multirow{2}{*}{ Average Daily Traffic } \\
\hline & & & Start & End & (mph) & $(\mathbf{k m} / \mathbf{h})$ & \\
\hline Rothwell & Faurot & WB & $10 / 22 / 08$ & $10 / 24 / 08$ & 27 & 44 & 131 \\
\hline Rothwell & Faurot & WB & $2 / 17 / 09$ & $2 / 19 / 09$ & 24 & 39 & 63 \\
\hline Rothwell & Rothwell & SB & $10 / 22 / 08$ & $10 / 24 / 08$ & 37 & 60 & 347 \\
\hline Rothwell & Rothwell & SB & $2 / 17 / 09$ & $2 / 19 / 09$ & 31 & 50 & 340 \\
\hline Shepard & Audubon & NB & $10 / 28 / 08$ & $10 / 30 / 08$ & 29 & 47 & 875 \\
\hline Shepard & Audubon & NB & $3 / 3 / 09$ & $3 / 5 / 09$ & 28 & 46 & 869 \\
\hline Shepard & Audubon & NB & $4 / 29 / 09$ & $5 / 1 / 09$ & 27 & 44 & 897 \\
\hline Shepard & Falcon & SB & $10 / 28 / 08$ & $10 / 30 / 08$ & 31 & 50 & 134 \\
\hline Shepard & Falcon & SB & $3 / 3 / 09$ & $3 / 5 / 09$ & 27 & 43 & 48 \\
\hline Shepard & Falcon & SB & $4 / 29 / 09$ & $5 / 1 / 09$ & 25 & 41 & 57 \\
\hline
\end{tabular}

Table 4. Summary of Statistical Tests Performed on Columbia data

\begin{tabular}{|c|c|c|c|c|c|c|c|c|}
\hline Neighborhood & Street & Dir./Study & $\begin{array}{l}\Delta \text { Ave. Spd. } \\
(\mathrm{km} \mid \mathrm{h} / \mathrm{mph})\end{array}$ & Std. Dev. Diff. & p Value & Stat. Sig.? & $\Delta 85 \%$ Speed $(\mathrm{km} \backslash \mathrm{h} / \mathrm{mph})$ & $\% \Delta$ Ave. Spd. \\
\hline Rothwell & Faurot & WB & $4.51 / 2.80$ & -2.00 & 0.00108 & Yes & $0.00 / 0.00$ & 10.3 \\
\hline Rothwell & Rothwell & SB & $9.99 / 6.21$ & 1.20 & $4.020 \mathrm{E}-47$ & Yes & $11.3 / 7$ & 16.6 \\
\hline Shepard & Audubon & NB & $1.61 / 1.00$ & -0.08 & $3.60 \mathrm{E}-09$ & Yes & $1.61 / 1$ & 3.39 \\
\hline Shepard & Falcon & SB & $7.00 / 4.35$ & 3.56 & $2.27 \mathrm{E}-06$ & Yes & $14.5 / 9.00$ & 13.9 \\
\hline Shepard & Audubon & Ed. Camp. & $1.08 / 0.67$ & -1.43 & $2.74 \mathrm{E}-10$ & Yes & $0.805 / 0.50$ & 2.35 \\
\hline Shepard & Falcon & Ed. Camp. & $2.82 / 1.75$ & -2.37 & 0.0541 & No & $0.00 / 0.00$ & 6.50 \\
\hline
\end{tabular}


Table 5. Summary of Answers to the Survey Administered to Residents in Columbia, MO

\begin{tabular}{|c|c|c|c|}
\hline \multirow{2}{*}{ Survey Question } & \multicolumn{3}{|c|}{ Percent of Answers by Neighborhood } \\
\hline & & Shepard & Rothwell \\
\hline \multirow{2}{*}{ Are you aware that your neighborhood speed limit was reduced from $30 \mathrm{mph}$ down to $25 \mathrm{mph}$ ? } & Yes & $93 \%$ & $50 \%$ \\
\hline & No & $7 \%$ & $50 \%$ \\
\hline \multirow{5}{*}{ How long have you been a resident in this neighborhood? } & $0-10$ years & $55 \%$ & $35 \%$ \\
\hline & $11-20$ years & $26 \%$ & $20 \%$ \\
\hline & 21-30 years & $7 \%$ & $8 \%$ \\
\hline & $31-40$ years & $9 \%$ & $35 \%$ \\
\hline & More than 40 years & $3 \%$ & $2 \%$ \\
\hline \multirow{6}{*}{$\begin{array}{l}\text { Because the posted speed limits were reduced for the streets in your neighborhood, are you now } \\
\text { (answer from list at right) to walk around the neighborhood? }\end{array}$} & Much more inclined & $14.3 \%$ & $2.5 \%$ \\
\hline & More inclined & $35.7 \%$ & $17.5 \%$ \\
\hline & Less inclined & $0.0 \%$ & $5.0 \%$ \\
\hline & Much less inclined & $0.0 \%$ & $0.0 \%$ \\
\hline & Makes no difference & $50.0 \%$ & $65.0 \%$ \\
\hline & No answer & $0.0 \%$ & $10.0 \%$ \\
\hline \multirow{6}{*}{$\begin{array}{l}\text { Because the posted speed limits were reduced for the streets in your neighborhood, do you now think } \\
\text { that most vehicles travel: }\end{array}$} & $\begin{array}{l}\text { Significantly under the } \\
\text { speed limit }\end{array}$ & $0.0 \%$ & $0 \%$ \\
\hline & Under the speed limit & $2.4 \%$ & $2.5 \%$ \\
\hline & $\begin{array}{l}\text { At the posted speed } \\
\text { limits }\end{array}$ & $52.4 \%$ & $7.5 \%$ \\
\hline & Over the speed limit & $42.8 \%$ & $62.5 \%$ \\
\hline & $\begin{array}{l}\text { Significantly over the } \\
\text { speed limit }\end{array}$ & $0 \%$ & $20.0 \%$ \\
\hline & No answer & $2.4 \%$ & $7.5 \%$ \\
\hline \multirow{6}{*}{$\begin{array}{l}\text { Because the posted speed limits were reduced for the streets in your neighborhood, how safe do you } \\
\text { feel now walking in your neighborhood? }\end{array}$} & Very unsafe & $0.0 \%$ & $7.5 \%$ \\
\hline & Unsafe & $0.0 \%$ & $17.5 \%$ \\
\hline & Normal & $40.5 \%$ & $50.0 \%$ \\
\hline & Safe & $47.6 \%$ & $12.5 \%$ \\
\hline & Very safe & $11.9 \%$ & $7.5 \%$ \\
\hline & No answer & $0.0 \%$ & $5.0 \%$ \\
\hline \multirow{6}{*}{$\begin{array}{l}\text { Because the posted speed limits were reduced for the streets in your neighborhood, how safe do you } \\
\text { feel now bicycling in your neighborhood? }\end{array}$} & Very unsafe & $0.0 \%$ & $10.0 \%$ \\
\hline & Unsafe & $0.0 \%$ & $15.0 \%$ \\
\hline & Normal & $45.2 \%$ & $45.0 \%$ \\
\hline & Safe & $21.4 \%$ & $10.0 \%$ \\
\hline & Very safe & $14.3 \%$ & $2.5 \%$ \\
\hline & No answer & $19.1 \%$ & $17.5 \%$ \\
\hline \multirow{2}{*}{ How often do you use the car? } & Few times a week & $4.8 \%$ & $10.0 \%$ \\
\hline & Daily & $95.2 \%$ & $90.0 \%$ \\
\hline
\end{tabular}

In both neighborhoods the largest percentage of answers indicate that the reduction in speed limits will not influence their decision to walk or ride bicycles more frequently around the neighborhood. However, in the Shepard Boulevard neighborhood, residents felt safe walking and riding bicycles on neighborhood streets.

\section{CONCLUSION}

The results from pilot projects in Springfield and Columbia, Missouri, showed that there was a statistically significant reduction in average speeds in all of the streets where the posted speed limit was reduced from $30 \mathrm{mph}(48$ $\mathrm{km} / \mathrm{h})$ to $25 \mathrm{mph}(40 \mathrm{~km} / \mathrm{h})$. In Springfield, a spillover effect 
was observed where speed reductions resulted on adjacent streets where the speed limit was not reduced.

The three stage experiment performed in the City of Columbia showed that both the use of conventional and special (oversized and attention attracting) signs produced decreases in average speeds. Residents of the neighborhood where the special signs were used reported a heightened perception of safety due to the lowered speed limit. The experiment also showed that the use of an educational campaign produced minimal or statistically insignificant incremental reduction in average speeds. As a result of the pilot projects, both cities expanded the $25 \mathrm{mph}$ speed limit to all local streets in their respective cities.

\section{ABBREVIATIONS}

$$
\begin{array}{ll}
\text { ADT } & =\text { Average Daily Traffic } \\
\text { FARS } & =\text { Fatal Analysis Reporting System } \\
\text { MUTCD } & =\text { Manual of Uniform Traffic Control Devices } \\
\text { SRTS } & =\text { Safe Routes to Schools }
\end{array}
$$

\section{GLOSSARY}

Pace Car $=\mathrm{A}$ car driven by a neighborhood resident who pledges to drive within the speed limit.

Residential Street $=$ Streets located within the boundaries of a residential neighborhood characterized by low volumes (under 1000 average daily traffic), low speeds and high density.

\section{CONFLICT OF INTEREST}

This work was sponsored in part by the Cities of Columbia and Springfield, Missouri, USA.

\section{ACKNOWLEDGEMENTS}

The authors acknowledge the kind assistance provided by Councilwoman Barbara Hoppe, PedNet President Ian Thomas and city engineer Scott Bitterman from the City of Columbia, Missouri and Beverly Beuerlein at the City of Springfield.

\section{REFERENCES}

[1] National Highway Traffic Safety Administration,Fatality Analysis Reporting System Encyclopedia. 2010, April 29; Available at: http://www-fars.nhtsa.dot.gov/Main/index.aspx

[2] Federal Highway Administration, "Road Function Classification," Washington, D.C.: FHWA Safety, 2000

[3] R. Stone, "Residential Street Speed Limit Report," Columbia, MO, 2007.

[4] $\quad$ Federal Highway Administration," Safe Routes To School Programs," Washington, D.C.: FHWA Safety, 2005.

[5] A.M. Dellinger, "Barriers to Children Walking and Biking to School," National center for injury prevention and control Department of health and human services, Atlanta, GA, 1999.

[6] M. Taylor, D.Lynam and A. Baruya,"The Effects of Drivers Speed on the Frequencyof Road Accidents," Transportation Research Laboratory, United Kingdom, Rep. 421, 2000.

[7] Turner-Fairbank Highway Research Center."Effects of Raising and Lowering Speed Limits," Federal Highway Administration (FHWA), U.S. Department of Transportation McLean, VA, Publication FHWA-RD-92-084, 1992.

[8] E. Newman, "Rountree Neighborhood $25 \mathrm{mph}$ Speed Limit Pilot Project, "Springfield, MO, USA, 2006.

[9] Federal Highway Administration, Manual on Uniform Traffic Control Devices.Washington, D.C.: FHWA, 2003.

[10] Salt Lake City Community \& Economic Development Department. Neighborhood Pace Car Program. 2010, November, 14; Available: http://www.ci.slc.ut.us/transportation/TrafficManagement/pacecar. htm

[11] Federal Highway Administration, Flexibility in Highway Design. Washington, D.C.: FHWA, 1997.

[12] Engineering Statistics Handbook. National Institute of Standards and Technology. Gaithersburg, MD, 2010. 